\title{
A makrogyürüben foszforatomot tartalmazó koronaéterek előállítása és alkalmazási lehetőségeinek vizsgálata ${ }^{+}$
}

\author{
SZABÓ-SZENTJÓBI Hajnalka ${ }^{\mathrm{a}}$, TÓTH Tünde ${ }^{\mathrm{a}, \mathrm{b}}$, HUSZTHY Péter ${ }^{\mathrm{a},{ }^{*}}$ \\ ${ }^{a}$ Budapesti Müszaki és Gazdaságtudományi Egyetem, Vegyészmérnöki és Biomérnöki Kar, \\ Szerves Kémia és Technológia Tanszék, Szent Gellért tér 4., 1111 Budapest, Magyarország \\ ${ }^{b}$ Energiatudományi Kutatóközpont, Energia- és Környezetbiztonsági Intézet \\ Konkoly Thege Miklós út 29-33, 1121 Budapest, Magyarország
}

\section{Bevezetés}

A szupramolekuláris kémia napjainkra egy jelentős tudományággá nőtte ki magát, alapja molekuláris felismerés, mely során a létrejövő asszociátumot intermolekuláris másodrendü kötőerők tartják össze. Ezt a jelenséget sokáig a természetben egyedülállónak tekintették, az ott előforduló számos példa közül megemlíthetjük az antitest-antigén kapcsolatot, vagy a DNS kettős csavarjának kialakulását ${ }^{1}$. Az, hogy a szintetikus úton elöállított vegyületek között is elkezdődhetett a molekuláris felismerés vizsgálata, $C$. $J$. Pedersen nevéhez köthető, aki egy véletlen folytán előállított egy koronaétert, és észrevette, hogy az ilyen típusú makrociklusok a korábbi ismeretekhez képest szokatlan komplexképző készséggel rendelkeznek ${ }^{2}$.

A foszforatom előfordulhat rendkívül sokféle kémiai környezetben, régóta foglalkoznak szerves és szervetlen vegyületeivel. Így nem meglepö, hogy a koronaéterekkel kapcsolatos kutatások területén is találkozhatunk számos olyan szakirodalmi példával, ahol a foszforatomot valamilyen formában a makrociklusokhoz kötik. Sok kutatás célja olyan vegyületek előállítása, amelyben a foszforatom valamilyen koordinációs szerepet tölt be, mint foszfin származék, más esetekben különböző foszfát- vagy foszforsav származékként jelenik meg a heterociklusokban. Az 1. ábrán a teljesség igénye nélkül néhány foszforatomot tartalmazó makrociklust és ezek változatos felhasználási lehetőségét mutatom be ${ }^{3}$. Kutatási témám alapjául diarilfoszfinsav és trifenilfoszfin egységet tartalmazó koronaéterek előállításával, tulajdonságaival, és felhasználási lehetőségeinek vizsgálatával foglalkozó kutatások szolgáltak ${ }^{4-8}$.

\section{Eredmények}

2.1. Új, deprotonálható koronaéterek szintézise és transzportfolyamatokban való vizsgálata

Transzportfolyamatok alatt azt értjük, amikor egy adott közegből valamilyen anyagot átjuttatunk egy másik közegbe egy membránrétegen keresztül. Ilyen folyamatokra számos példát találhatunk az élő természetben is, például a nátrium- és káliumionok transzportját a sejtekben. Sok kutatás irányul ezen folyamatok modellezésére, a kutatók már régóta próbálnak mesterséges rendszereket és transzport-molekulákat előállítani, melyekkel ezek a folyamatok megvalósíthatók. Doktori munkám egyik célja volt új, enantiomertiszta, lipofil, diarilfoszfinsav egységet tartalmazó koronaéterek $((R, R)-\mathbf{5},(S, S)-\mathbf{5},(R, R)-\mathbf{6}$, és $(S, S)-6,2$. ábra) szintézisének kidolgozása, illetve ezek transzporter-ligandumként történő alkalmazhatóságának vizsgálata volt $[1,2]$. Az általam szintetizált deprotonálható makrociklusokkal különböző királis aminok sóinak enantiomerszelektív transzport-folyamatait vizsgáltam a kutatócsoportban korábban kidolgozott rendszerben ${ }^{6}$. Sikerült a korábban előállított hasonló szerkezetü makrociklusokkal $((R, R)-\mathbf{7},(S, S)-7,(R, R)-\mathbf{8}$, és $(S, S)-\mathbf{8}$, 2. ábra) elért enantiomerfelesleg értékeket javítani.

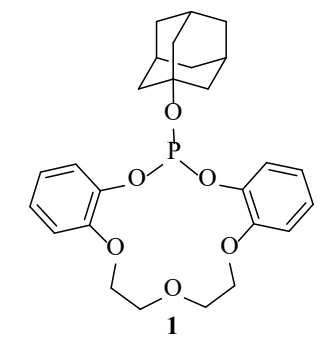

Fémionok komplexálásának vizsgálata

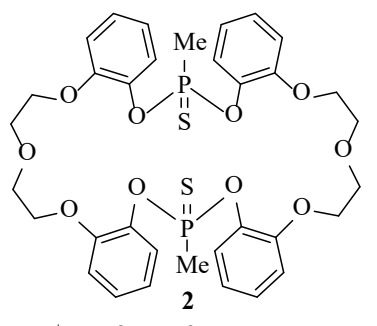

$\mathrm{Ag}^{+}, \mathrm{Hg}^{2+}, \mathrm{Pd}^{2+}$ extrakciója

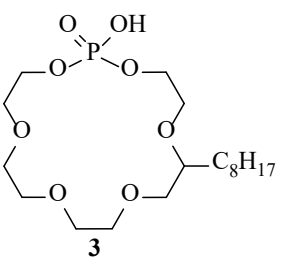

$\mathrm{K}^{+}, \mathrm{Pb}^{2+}, \mathrm{Zn}^{2+}, \mathrm{Ag}^{+}$ transzportja

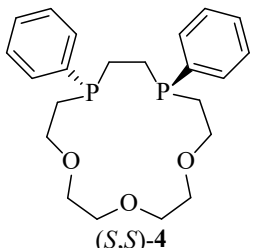

$\mathrm{Pd}^{2+}$ komplexe katalizátor $\alpha, \beta$-telítetlen ketonok addíciós reakciójában

1. Ábra. Foszforatomot tartalmazó makrociklusok és alkalmazhatóságuk

\footnotetext{
+ Szabó-Szentjóbi Hajnalka azonos című PhD értekezéséhez kapcsolódó Tézisfüzet alapján készült

* Tel.: 0614631071 ; fax: 0614633297 ; e-mail: huszthy@mail.bme.hu
} 


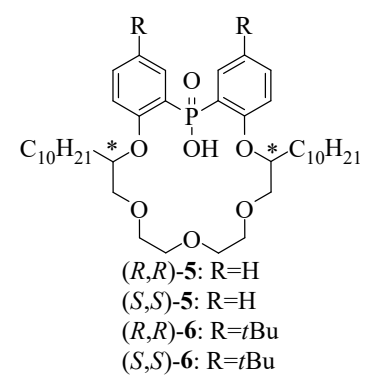

A királis vegyületek szintézisénél rac-1,2-epoxidodekánból (rac-9) indultam ki. Egy kinetikai rezolválási eljárás során mindkét enatiomert nagy tisztasággal izoláltam, majd az enaniomertiszta epoxidokat sikeresen tovább alakítottam, míg végül a megfelelő $(S, S)-5$ - $(R, R)$-6 diarilfoszfin-savakhoz jutottam (3. ábra).

2. Ábra. Deprotonálható diarilfoszfinsav egységet tartalmazó koronaéterek

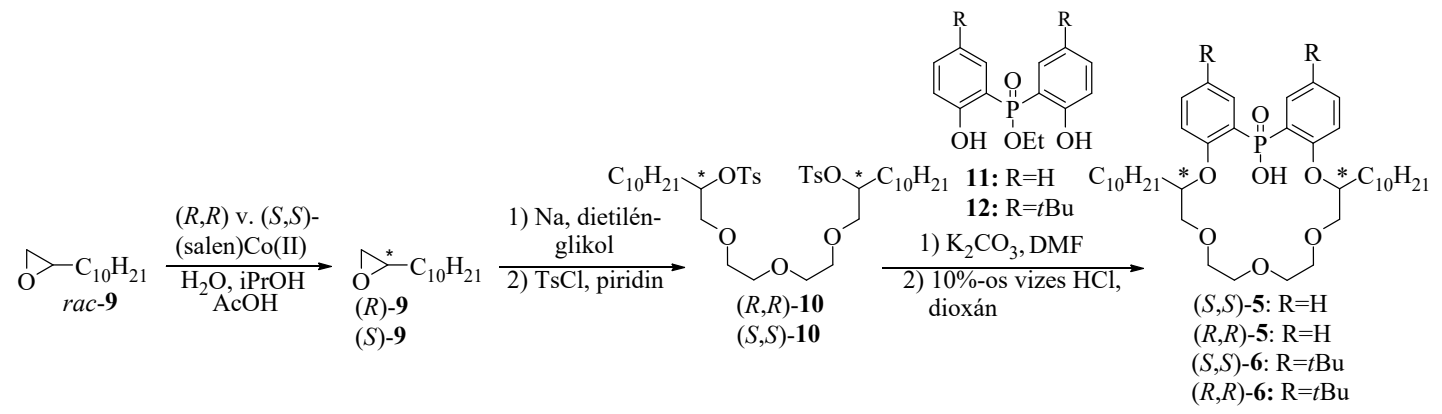

3. Ábra. A diarilfoszfinsav egységet tartalmazó koronaéterek szintézise

Az enantiomertiszta makrociklusok transzport-tulajdonságainak hasznosítására kutatócsoportunk-ban kidolgozott módszer szerint királis protonált primer aminok enantiomerszelektív transzportját vizsgáltam egy vizes adófázis-szerves membrán-vizes szedőfázis rendszerben ${ }^{6} . \mathrm{Az}$ eredmények szerint a transzport kimenetele jelentősen függ mind a transzportáló makrociklus, mind pedig a transzportált protonált amin szerkezetétől. Az eredményeket öszszefoglaló táblázatban az össze-hasonlíthatóság kedvéért a korábban elöállított makrociklusokkal elért eredményeket is feltüntettem (4. ábra).

\begin{tabular}{|c|c|c|c|}
\hline Amin (A*COH) & Ligandum & $\begin{array}{c}\text { Transzportált } \\
\text { mennyiség } \\
\text { (\%) }\end{array}$ & $\begin{array}{c}\text { Enantiomer } \\
\text { felesleg (\%) }\end{array}$ \\
\hline $\begin{array}{c}\text { Feniletil-amin } \\
\text { (4óra) }\end{array}$ & $(S, S)-\mathbf{5}[(S, S)-7]$ & $13[14]$ & $0[13]$ \\
\cline { 2 - 4 } & $(S, S)-6[(S, S)-8]$ & $15[31]$ & $0[4]$ \\
\hline $\begin{array}{c}\text { Fenilglicinol } \\
\text { (24 óra) }\end{array}$ & $(S, S)-\mathbf{5}[(S, S)-7]$ & $22[24]$ & $20[12]$ \\
\cline { 2 - 4 } & $(S, S)-6[(S, S)-8]$ & $19[24]$ & $18[17]$ \\
\hline \multirow{2}{*}{$\begin{array}{c}\text { Fenilalaninol } \\
\text { (24 óra) }\end{array}$} & $(S, S)-5$ & 21 & 8 \\
\cline { 2 - 4 } & $(S, S)-6$ & 22 & 4 \\
\hline \multirow{2}{*}{ Efedrin } & $(S, S)-5$ & 29 & 2 \\
\cline { 2 - 4 } & $(S, S)-6$ & 38 & 0 \\
\hline
\end{tabular}

4. Ábra. Az enantiomerszelektív transzport eredményei

Fenilglicinol-hidrogénperklorát sójának esetében sikerült javítani az alkalmazott rendszerben eddig elért legjobb enantiomerfelesleg értéket. Ebben az esetben vizsgáltam a transzport időfüggését is, amivel bizonyítottam az aktív transzport müködését. A transzport során tapasztalható enantiomerfelesleg értékek meglepően egy maximumon átívelő görbe szerint alakultak, ezért megvizsgáltam a transzportot koronaéter távollétében is, melynek során membránszivárgást tapasztaltam a fenilglicinol diklórmetában való oldhatósága miatt. Ez a folyamat az enantiomerek elválasztásának ellenében hat, így feltételeztem, hogy a szivárgás és a tényleges transzport, mint két ellentétes folyamat alakítja ki az enantiomerfelesleg értékek alakulását. Megállapítot-tam, hogy a transzportok esetén a heterokirális komplexek képződése preferált (5. ábra) $)^{9,10}$.

\begin{tabular}{|c|c|c|}
\hline Idő (óra) & $\begin{array}{c}\text { Transzportált } \\
\text { mennyiség (\%) }\end{array}$ & $\begin{array}{c}\text { Enantiomer } \\
\text { felesleg (\%) }\end{array}$ \\
\hline 4 & 5 & 15 \\
\hline 16 & 15 & 18 \\
\hline 24 & 21 & 20 \\
\hline 50 & 32 & 25 \\
\hline 74 & 40 & 26 \\
\hline 120 & 56 & 25 \\
\hline 172 & 68 & 19 \\
\hline 231 & 72 & 10 \\
\hline
\end{tabular}

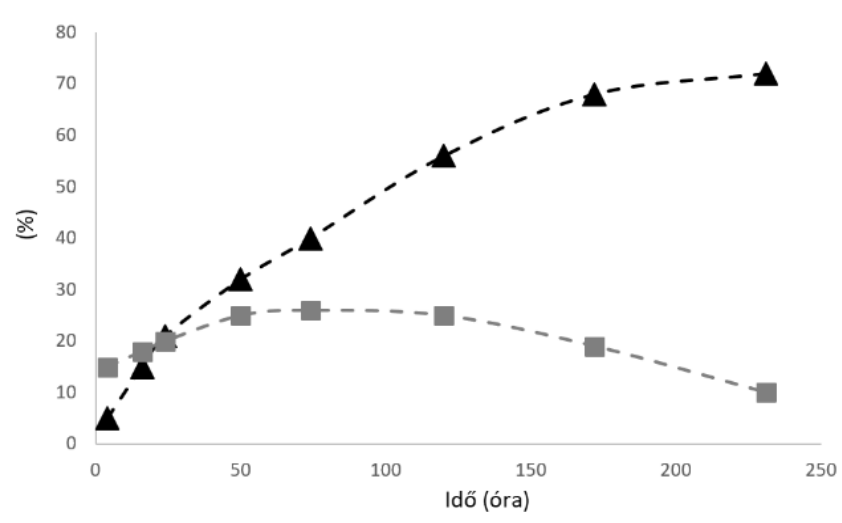

5. Ábra. A fenilglicinol enantioszelektív transzportjának időfüggése 


\subsection{Fluoreszcens szenzormolekulák szintézise és vizsgálata}

Kutatócsoportunkban nagy hagyománya van a fluoreszcens szenzormolekulák szintézisének. A változatos szerkezetü koronaéterek különböző mértékü enantiomerszelektivitással képesek fel-ismerni protonált primer aminok enantiomerjeit. Célul tűztem ki egy foszforatomot tartalmazó fluoreszcens szenzormolekula mindkét enantio-merjének előállítását $((S, S)$-13 és $(R, R)$-13) és vizsgálni ezek protonált aminok enantiomerjeivel szemben mutatott felismeröképességét. A szenzor-molekák szintéziséhez először a tet- raetilénglikol-ditozilátok enantiomerjeit állítottam ellő. Az $(S, S)-14$ intermediert a szakirodalomban közölt módon állítottam elö, az $(R, R)-14$ enantiomer szintézisére pedig egy új módszert dolgoztam ki, melynek első lépése a lipofil tetraetilénglikol előállításánál (3. ábra) is használt kinetikus rezolválás volt. Az így kapott $(R)$-propilénoxidot alakítottam tovább a megfelelő tetraetilénglikol származékká. A makrociklizációs lépés után a fluoreszcens egység bevitelére több kísérletet tettem, többek között Grignard-, lítiumorganikus- valamint Hirao-reakcióval is. A legeredményesebb P-C kapcsolás körülményeit a 6. ábrán mutatom be ${ }^{11}$.

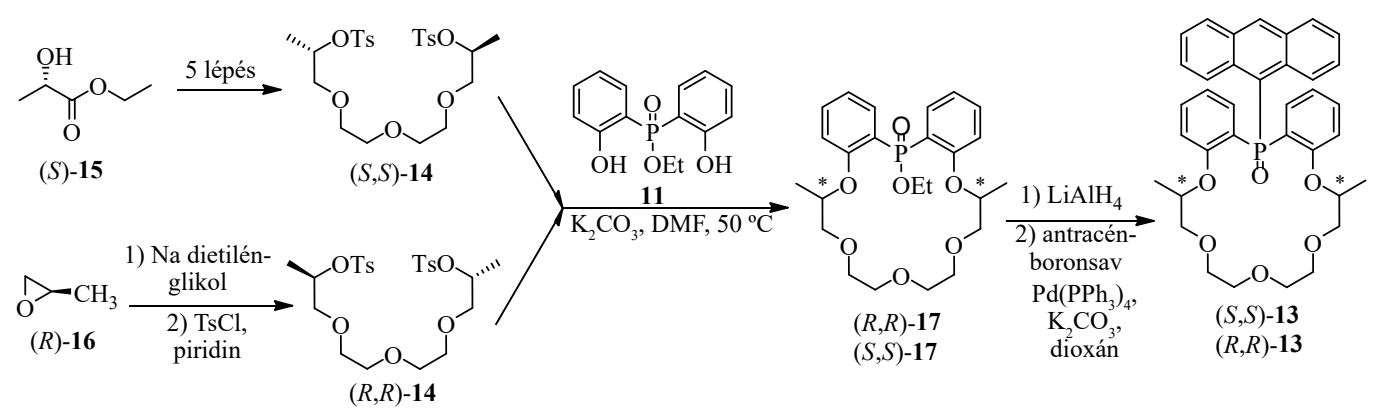

6. Ábra. Foszforatomot tartalmazó fluoreszcens szenzormolekula előállítása

Az előállított koronaéterek komplex szerkezete miatt, szerettük volna kétdimenziós NMR spektroszkópia segítségével alátámasztani azt. A méréseket Szigetvári Áron végezte Dr. Szántay Csaba vezetésével. Habár a makrociklusok szimmetrikusak, a foszfor atom egy prokirális centrum, így a makrociklus két fele diasztereotóp viszonyban áll egymással. Emiatt minden atom különböző eltolódással jelenik meg a NMR spektrumokban, azonban igen közel egymáshoz, így a jelek beazonosítása rendkívül bonyolult feladatnak bizonyult. Az $(S, S)-\mathbf{1 3}$ koronaéter teljes asszignációját elvégezték ${ }^{11}$.

Az $(R, R)$-13 és $(S, S)$-13 szenzormolekulák enantiomerfelismerő-képességét fluoreszcencia spektroszkópia segítségével vizsgáltam 1-feniletil-amin- hidrogénperklorát (PEA), 1-(1-naftil)etil-amin-hidrogénperklorát (NEA), fenilglicin-meti-lészter-hidrogénperklorát (PGMA) és fenilalanin-metilészter-hidrogénperklorát (PAMA) enantiomer-jeivel szemben (7. ábra).

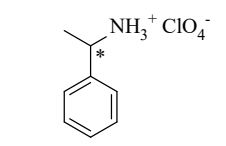

$(R)$ - és $(S)$-PEA

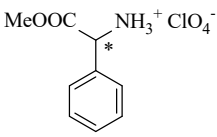

$(R)$ - és $(S)$-PGMA

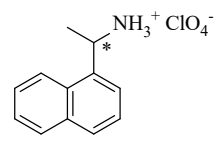

$(R)$ - és $(S)$-NEA

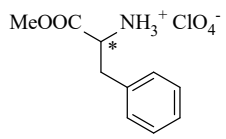

$(R)$ - és $(S)$-PAMA
7. Ábra. Vizsgált aminok hidrogénperklorát sói

A szenzormolekulák komplexképzésére jellemző spektrális változásokat, valamint az ebböl képzett Stern-Volmer görbéket az $(R, R)$-13 korona-éter és az $(R)$-PGMA példáján mutatom be (8. ábra). Az $(R, R)$-13 és $(S, S)$-13 makrociklusok esetében minden vizsgált protonált aminnal negatív eltérést tapasztaltam a Stern-Volmer egyeneshez képest. Ebben az esetben a komplexstabilitási állandók számítása nehezebb, nem egyértelmű az összefüggés a fluoreszcencia intenzitásának csökkenése és a komplexstabilitási állandók között ${ }^{12}$.
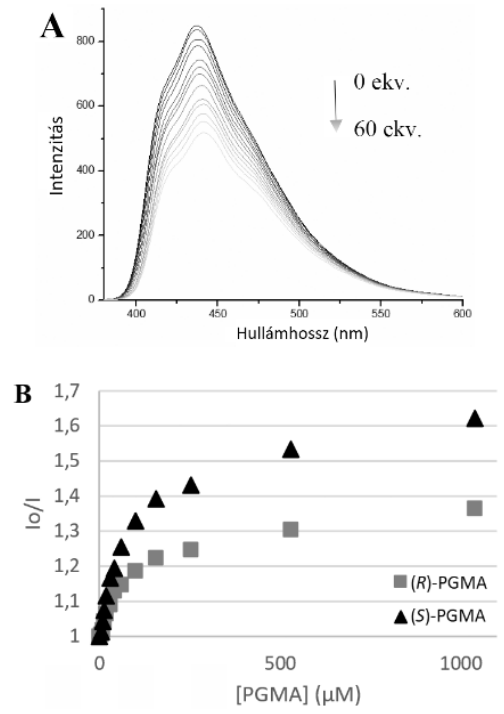

8. Ábra. $\mathrm{Az}(R, R)-\mathbf{1 3}$ makrociklus $(R)$-PGMA oldatával történő titrálása során kapott fluoreszcencia spektrum-sorozat $(\mathrm{A})$, az $(R, R)-13$ makrociklus PGMA enatiomerjeivel végzett mérések alapján kapott Ster-Volmer görbék (B)

A komplexstabilitási állandók számításait Dargó Gergő végezte Dr. Balogh György Tibor vezetésével. Az eredményekből látszik, hogy a koronaéterek viszonylag stabil komplexet képeznek a vizsgált protonált aminokkal, a log $K$ értékek minden esetben 4 körül vannak. A PGMA és a 
PAMA esetében a homokirális komplexek, míg a NEA és a PEA esetében a heterokirális komplexek képződése preferált. Az eredmények alapján azt is láthatjuk, hogy a koronaéterek enantiomerfelismerő-képessége csak gyenge, közepes (9. ábra)

\begin{tabular}{|c|c|c|c|c|}
\hline & \multicolumn{5}{|c|}{$\log K$} \\
\hline & $(R)$-NEA & $(S)$-NEA & $(R)$-PEA & $(S)$-PEA \\
\hline$(R, R)-\mathbf{1 3}$ & 4,29 & 4,37 & 3,97 & 4,03 \\
\hline$\Delta \log K$ & \multicolumn{3}{|c|}{0,08} & \multicolumn{3}{c|}{0,06} \\
\hline$(S, S S)$-13 & 4,21 & 4,14 & 4,12 & 4,01 \\
\hline$\Delta \log K$ & \multicolumn{3}{|c|}{0,07} & \multicolumn{3}{|c|}{0,11} \\
\hline & $(R)$-PGMA & $(S)$-PGMA & $(R)$-PAMA & $(S)$-PAMA \\
\hline$(R, R)-\mathbf{1 3}$ & 4,43 & 4,28 & 3,99 & 3,82 \\
\hline$\Delta \log K$ & \multicolumn{3}{|c|}{0,15} & \multicolumn{3}{|c|}{0,17} \\
\hline$(S, S)$-13 & 4,26 & 4,36 & 3,99 & 4,10 \\
\hline$\Delta \log K$ & \multicolumn{3}{|c|}{0,10} & \multicolumn{3}{|c|}{0,11} \\
\hline
\end{tabular}

9. Ábra. Szenzormolekulák protonált primer aminokkal képzett komplexeinek stabilitási állandói

\subsection{Foszfin és szekunder foszfin-oxid egységet tartalmazó koronaéterek szintézise és vizsgálata katalizátor ligandumként}

Kutatócsoportunkban korábban kis mennyiségben előállították a 18, $(R, R)$-19 és az $(S, S)$-20 (10. ábra) trifenilfoszfin egységet tartalmazó makrociklusokat. Doktori munkám során a leírt szintézisétutakat reprodukálva sikerült ezen koronaétereket nagyobb mennyiségben is elöállítanom, így lehetőség nyílt ezen vegyületek katalizátorligandumként való vizsgálatára sztirol hidroformilezési reakciójában. A vizsgálatokat $D r$. Pongrácz Péter végezte $D r$. Kollár László vezetésével. A reakció minden esetben egy nyomásálló edényben zajlott, ebbe került a $\mathrm{PtCl}_{2}(\mathrm{PhCN})_{2}$ és a ligandum (vagy az ezekböl előzetesen kialakított katalizátor), valamint a kokatalizátorként használt ón-klorid toluolban készült oldata. A nyomásálló edényt 80 bar nyomás alá helyezték, ahol a szénmonoxid:hidrogén gáz-nyomás aránya 1:1 volt. A reakció során elágazó (A) és lineáris aldehid (B) is keletkezik, valamint hidrogénezési mellékreakció is lejátszódik, melynek terméke az etilbenzol (C), így vizsgálható a reakció kemo- $((\mathbf{A}+\mathbf{B}) /$ $(\mathbf{A}+\mathbf{B}+\mathbf{C}))$ és regioszelektivitása $(\mathbf{A} /(\mathbf{A}+\mathbf{B}))$. Amennyiben az alkalmazott ligandum királis, úgy a 2-fenilpropanal enantiomerjei racémtől eltérő arányban keletkezhetnek, azaz a reakció enantiomerszelektivitása is vizsgálhatóvá válik (10. ábra). A kutatás során vizsgálták a platina-ligandum arány, a reakcióidő, valamint a hőmérséklet reakcióra gyakorolt hatását. A kemoszelektivitás $63-90 \%$ között volt, tehát minden esetben az aldehidek keletkeztek nagyobb mennyiségben. A regioszelektivitás jellemzően $60 \%$ körül volt, az elágazó aldehid keletkezett nagyobb mennyiségben. A királis ligandumok alkalmazása esetén közepes enantiomer-szelektivitást sikerült elérni, a 2-fenilpropanal a legnagyobb (52\%) enantiomerfelesleg értékkel az $(S, S)-\mathbf{2 0}$ makrociklus alkalmazása esetén keletkezett ${ }^{13}$.

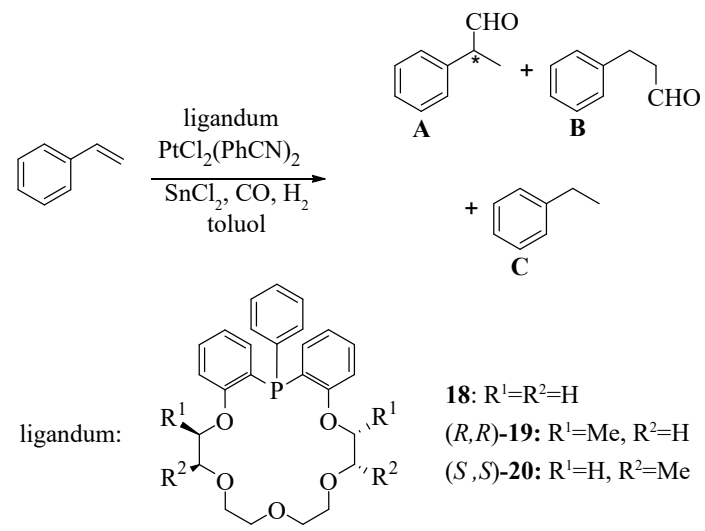

10. Ábra. Trifenilfoszfin egységet tartalmazó makrociklusok alkalmazása katalizátor ligandumként

Az ez irányú kutatásokat kiterjesztve előállítottam további hat új trifenilfoszfin egységet tartalmazó makrociklust $((S, S)-21$ - $(S, S, S, S)-26)$, valamint két szekunder foszfinoxid egységet tartalmazó korona-étert ( $(S, S)$-27 és $(S, S)$-28) is $^{14}$ (11. ábra). Ez utóbbi vegyületek a pentavalens foszfinoxid és a trivalens foszfinossav tautomer formák egyensúlyában léteznek Ez az egyensúly átmeneti fém hozzá-adásának hatására a foszfinossav irányába tolódik el, így ezek a vegyületek is alkalmasak lehetnek katalizátor prekurzorként történő felhasználásra amellett, hogy oxidációra jóval kevésbé érzékenyek, mint a foszfin típusú vegyületek ${ }^{15}$.

A szintéziseket a foszfin egységet tartalmazó koronaéterek közös, a szakirodalomban már közölt kulcsintermedierjének $\left(\mathbf{2 9}^{16}\right)$ előállításával kezdtem, melyet már kutatócsoportunk-
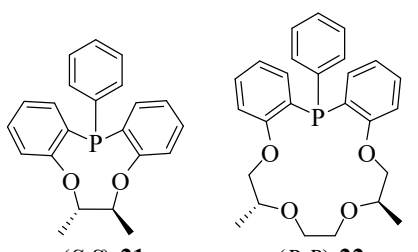

$(S, S)-21$

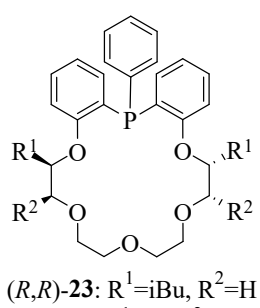

$(S, S)-24: \mathrm{R}^{1}=\mathrm{H}, \mathrm{R}^{2}=\mathrm{iBu}$
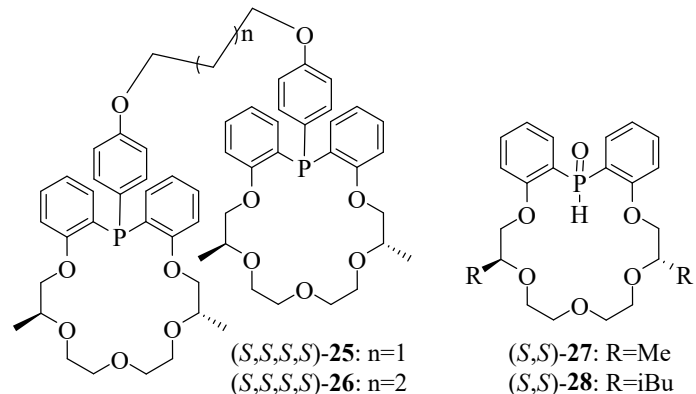

$(S, S)-\mathbf{2 7}: \mathrm{R}=\mathrm{Me}$

$(S, S)-28: \mathrm{R}=\mathrm{iBu}$

11. ábra. Trifenilfoszfin és szekunder foszfin-oxid egységet tartalmazó makrociklusok 
ban is előállították korábban ${ }^{11}$, azonban én ezt egy új, egyszerübben és gyorsabban kivitelezhető reakciókat magában foglaló szintézisúton állítottam elö. Első lépésként a 30 difenilklór-foszfátot vittem Grignard-reakcióba fenilmagnézium-bromiddal, így kaptam a $\mathbf{3 1}$ foszfonátot. Ezt reagáltattam tovább in situ képzett lítium-diizopropil-amiddal, amely révén egy orto-lítiálást követő intermolekuláris átrendezödés játszódott le, így jutottam a kívánt 29 foszfin-oxidhoz (12. ábra).

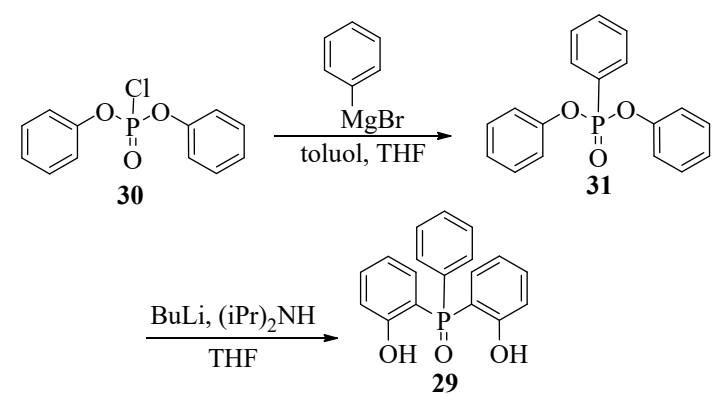

12. Ábra. A koronaéterek közös, foszfin-oxid egységet tartalmazó kulcsintermedierjének elöállítása

A szintézisek másik kulcsintermedierjei az etilénglikol-ditozilátok voltak, melyek közül a legtöbbet a szakirodalomban már közöltek. Az $(R, R)-22$ makrociklus előállításához szükséges, a szakirodalomban eddig nem közölt, $(R, R)-\mathbf{3 2}$ trietilénglikol-ditozilát előállítását az enantiomer-tiszta (S)-33 2-brómproprásavból kiindulva valósítottam meg. Elsőként utóbbi a nátrium sóját képeztem, melyet etilénglikollal reagáltattam. Az így kapott disav származékot metanolban tionil-kloriddal az $(R, R)$-35 diészterré alakítottam, amit lítium-alumínium-hidrid segítségével diollá redukál-tam, majd utolsó lépésként tozilát távozó-csoportokkal láttam el $((R, R)-32,13$. ábra $)$.
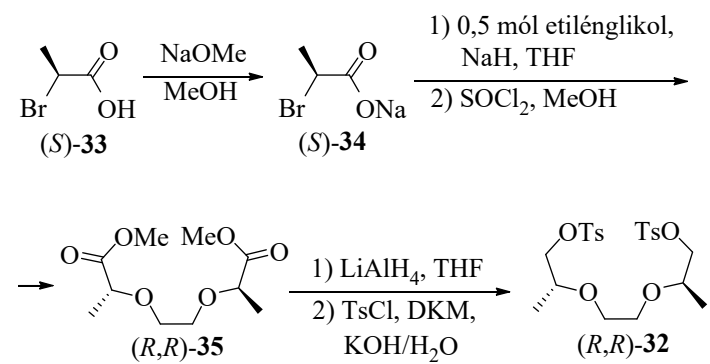

13. ábra. Dimetil-szubsztituált trietilénglikol-ditozilát előállítása

Az $(S, S)-21$ - $(S, S)$-24 makrociklusok elöállítása során a következő lépés a makrociklizáció volt, amit minden esetben valamilyen aprótikus poláros oldószerben végeztem, a hőmérsékletet aszerint megválasztva, hogy primer vagy szekunder ditozilátot vittem gyürüzárási reakcióba a 29 foszfin-oxiddal. Utolsó lépésként a foszfin-oxid egységet tartalmazó makrociklusokat trimetoxiszilán segítségével a megfelelő foszfinokká redukáltam $(14 \text {. ábra })^{15}$.
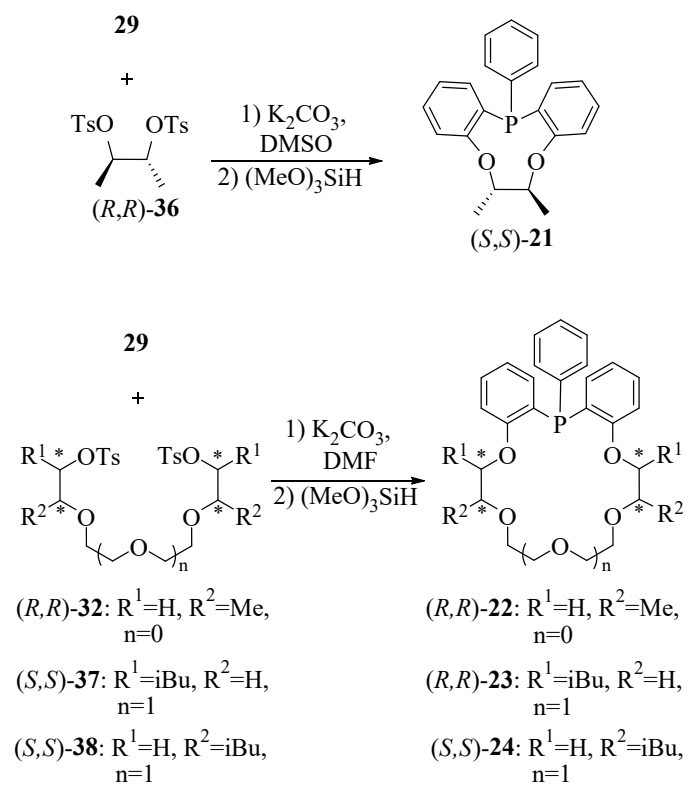

14. ábra. Makrociklizációs és redukciós reakciók

Az $(S, S, S, S)-\mathbf{2 5}$ és $(S, S, S, S)$-26 két foszfin egységet tartalmazó biszkoronaéter típusú vegyületek szintézise során az $(S, S)-$ 395 $^{5}$ etil-diarilfoszfinátból indultam ki, melyből savkloridot képeztem, majd ezt reagáltattam Grignard reakcióban 4-benziloxi-fenilmagnézium-bromiddal. Ezután katalitikus hidrogénezéssel a benzil védőcsoportot eltávolít-ottam, így jutottam az $(S, S)-40$ szabad fenolos hidroxilcsoportot tartalmazó származékhoz. Ennek két mólját egy mól különböző hosszúságú $\alpha, \omega$-dibróm-alkánokkal reagáltattam, majd az így kapott biszfoszfin-oxidokat utolsó lépésként redukáltam $(15 . \text { ábra })^{15}$
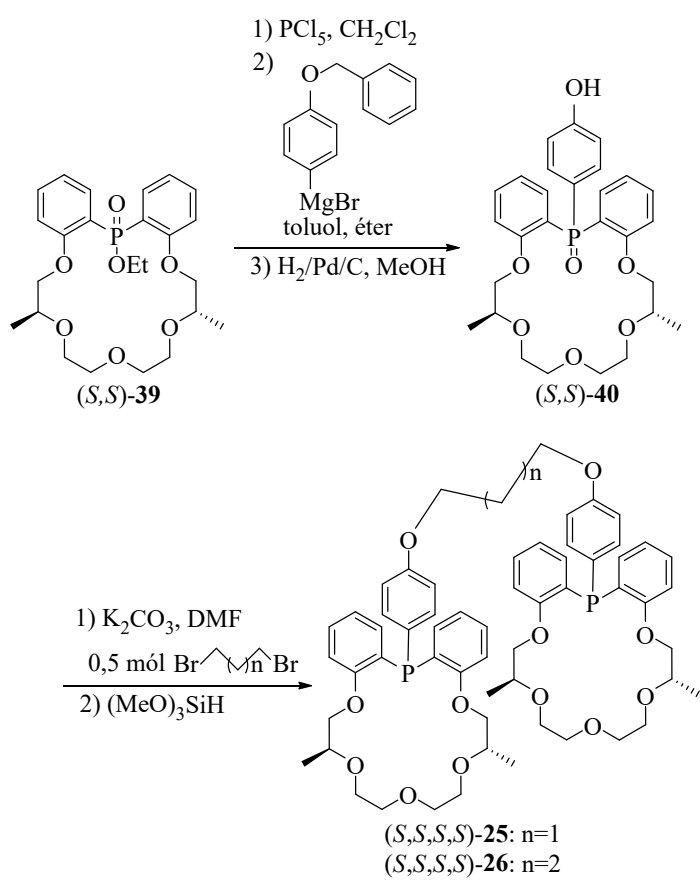

15. ábra. Biszmakrociklusok előállítása 
Az $(S, S)$-27 és $(S, S)$-28 szekunder foszfin-oxid egységet tartalmazó koronaétereket a megfelelő etil-diarilfoszfinátokból $((S, S)$-39 és $(S, S)$-41) állítottam elő, lítium-alumínium-hidriddel végzett redukcióval (16. ábra $)^{15}$.

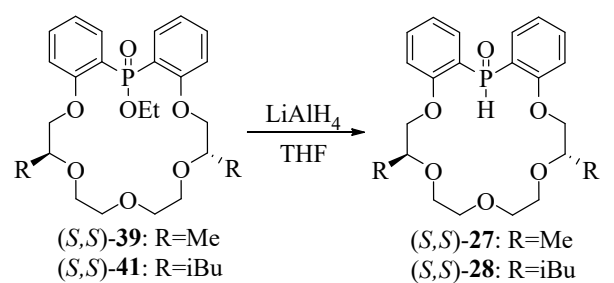

16. Ábra. Szekunder foszfin-oxid egységet tartalmazó koronaéterek előállítása

Az újonnan szintetizált makrociklusokat $((S, S)-\mathbf{2 1}$ - $(S, S)$-28) sztirol hidroformilezési reakciójában tervezzük katalizátor ligandumként alkalmazni. Így vizsgálhatóvá válik a ligandumok szerkezetének a választott modellreakció szelektivitására gyakorolt hatása.

\section{6. Összefoglalás}

Kutatómunkám során előállítottam két új, lipofil, diarilfoszfinsav egységet tartalmazó királis koronaétert $((R, R)-5$ - $(S, S)-6)$, melyekkel aktív, enantiomerszelektív transzportot valósítottam meg és bizonyítottam, hogy a transzportfolyamat kimenetele nagymértékben függ a transzportáló makrociklus és a transzportálandó amin szerkezetétől is. Egy esetben növeltem a transzportfolyamat során ilyen típusú makro-ciklusokkal eddig elért enantiomerfelesleg értéket. Ezen kívül előállítottam új, foszfor atomot tartalmazó fluoreszcens szenzormolekulát $((R, R)-\mathbf{1 3}$ és $(S, S)-\mathbf{1 3})$ is. Vizsgálva a szenzormolekula felismerőképességét négy királis, protonált primer amin enantiomerjeire vonatkozóan megállapítottam, hogy az gyenge enantiomerfelismerő-képességgel rendelkezik. A szakirodalomban közölt szintézisút szerint nagyobb mennyiségben előállított trifenilfoszfin egységet tartalmazó makro-ciklusokkal $((R, R)-\mathbf{1 9}$ és $(S, S)$-20), sikerült bizonyítanom, hogy ezen koronaéterek alkalmasak sztirol enantiomerszelektív hidroformilezési reakciójában katalizátor ligandumnak. Ezen kutatás kiterjesztéseként hat új foszfin $((S, S)-\mathbf{2 1}-(S, S, S, S)-\mathbf{2 6})$, és két új szekunder-foszfinoxid egységet tartalmazó koronaétert szintetizáltam $((S, S)$-27 - $(S, S)$-28), melyekkel a későbbiekben vizsgálni szeretnénk a ligandumok szerkezetének a választott modellreakció szelektivitására gyakorolt hatását.

\section{Köszönetnyilvánítás}

A szerzők köszönik a Nemzeti Kutatási, Fejlesztési és Innovációs Hivatal (K112289 és K128473), az Új Nemzeti Kiválóság Program (ÚNKP-19-3) és az Új Széchenyi Terv TÁMOP-4.2.1/B-09/1/KMR-2010-0002 program anyagi támogatását.

\section{Hivatkozások}

1. Lehn, J. M. Supramolecular Chemistry; WileyVCH: Weinheim, 1995. ISBN: 3-527-2931 1-6

2. Pedersen, C. J. Journal of the American Chemical Society 1967, 89, 2495.

https://doi.org/10.1021/ja00986a052 https://doi.org/10.1021/ja01002a035

3. Szabó-Szentjóbi, H.; Szabó, T.; Tóth, T.; Huszthy, P: Crown ethers containing phosphorus in the macroring, Chapter 15. Organophosphorus Chemistry, (ed.: Gy. Keglevich) 2018. ISBN: 978-3-11-053453-5 https://doi.org/10.1515/9783110535839-015

4. Huszthy, P.; Farkas, V.; Tóth, T.; Székely, G.; Hollósi, M. Tetrahedron 2008, 64, 10107. https://doi.org/10.1016/j.tet.2008.07.111

5. Székely, Gy.; Csordás, B.; Farkas, V.; Kupai, J.; Pogány, P.; Sánta, Z.; Szakács, Z.; Tóth, T.; Hollósi, M.; Nyitrai, J.; Huszthy, P. European Journal of Organic Chemistry 2012, 3396. https://doi.org/10.1002/ejoc.201101769

6. Szabó, T.; Hirsch, E.; Tóth, T.; Huszthy, P. Tetrahedron: Asymmetry 2014, 25, 1443.

https://doi.org/10.1016/j.tetasy.2014.10.006

7. Szabó, T.; Hirsch, E.; Tóth, T.; Müller, J.; Riethmüller, E.; Balogh, G. T.; Huszthy, P. Tetrahedron: Asymmetry 2015, 26,650 .

https://doi.org/10.1016/j.tetasy.2015.04.015 DOI:10.1016/j.tetasy.2015.04.015

8. Szabó, T.; Petri, L.; Gergely, S.; Huszthy, P. Arkivoc 2015, v, 20 , https://doi.org/10.3998/ark.5550190.p009.075

9. Szabó-Szentjóbi, H.; Tóth, T.; Huszthy, P. Phosphorus, Sulfur and Silicon and the Related Elements, 2018, 194, 364. https://doi.org/10.1080/10426507.2018.1544131

10. Szabó-Szentjóbi, H.; Bagi P.; Müller, J.; Balogh, Gy. T.; Tóth, T.; Huszthy, P. Tetrahedron, 2019, 75, 1275. https://doi.org/10.1016/j.tet.2019.01.039

11. Szabó-Szentjóbi, H.; Márton, A.; Pál, D.; Dargó, G.; Szigetvári, A..; Szántay, Cs.; Balogh, Gy., T.; Tóth, T.; Huszthy, P. Periodica Polytechnica Chemical Engineering 2020, 1,37 . https://doi.org/10.3311/PPch.14646

12. Van de Weert, M.; Stella, L., Journal of Molecular Structure 2011, 998, 144. https://doi.org/10.1016/j.molstruc.2011.05.023

13. Pongrácz, P.; Szentjóbi H.; Tóth, T.; Huszthy, P.; Kollár, L. Molecular Catalysis, 2017, 439, 128. https://doi.org/10.1016/j.mcat.2017.06.037

14. Szabó-Szentjóbi, H., Majoros, I. Márton, A., Leveles, I. Vértessy, B. G., Dékány, M., Tóth, T., Huszthy, P. Synthesis, közlésre elfogadva. 2020. 52. https://doi.org/10.1055/s-0040-1707854

15. Christiansen, A.; Li, C.; Garland, M.; Selent, D.; Ludwig, R.; Spannenberg, A.; Baumann, W.; Franke, R.; Boerner, A. European Journal of Organic Chemistry 2010, 2733. https://doi.org/10.1002/ejoc.201000037

16. Tanke, R. S.; Holt, E. M.; Crabtree, R. H. Inorganic Chemistry 1991, 30, 1714. https://doi.org/10.1021/ic00008a009 


\section{Synthesis and examination of the possibility for application of crown ethers containing phosphorus in the macroring}

Nowadays supramolecular chemistry has become an important area of research. Its basic phenomenon is the molecular recognition. Acting by this phenomenon a host molecule (a crown ether for example) selects a guest molecule from the surrounding molecules, and they form a complex stabilized by secondary binding forces. This phenomenon had been regarded for a long time as a unique one in Nature. Among many examples the antibody-antigen interaction or the formation of the DNA double helix can be mentioned $^{1}$. The study of molecular recognition using synthetic host molecules started by $C$. J. Pedersen who accidentally prepared a crown ether and realized that these types of macrocycles have unusual complexing properties ${ }^{2}$.

Phosphorus can be found in extremely divers chemical environments, occurs in many organic and inorganic compounds. Because of this, it is not surprising, that there are also a great number of reported examples in the field of research on crown ethers too, in which the phosphorus atom is bound to the macrocycles in certain form. The aim of many researches is to prepare compounds in which the phosphorus atom plays some coordination role as a phosphine derivative, in other cases it appears as a phosphate or phosphoric acid derivative in heterocycles. Figure 1 shows the schematics of some macrocycles containing phosphorus and also their various applications $\mathrm{s}^{3-6}$.

Studies on the synthesis and properties of crown ethers containing a triaryphosphine or diaryl-phosphinic acid moiety were the background of my research work ${ }^{7-11}$.

One of the aims of my $\mathrm{PhD}$ work was to elaborate the synthesis of new, enantiopure lipophilic crown ethers containing diarylphosphinic acid unit $((R, R)-\mathbf{5}-(S, S)-\mathbf{6}$, Fig. 2), and examine these compounds as transport ligands ${ }^{12,13}$. With the newly synthesized proton-ionizable macrocycles enantio-selective transport of chiral protonated amines was examined in a system previously developed in our research group ${ }^{9,10}$. I was able to achieve better enantioselectivity than before using similar macrocycles $((R, R)-7$ - $(S, S)-\mathbf{8}$, Fig. 2).The results show that the outcome of the transport depends significantly on the structure of the transporter macrocycle and the transported amine. The results are summarized in a table (Fig 4.), where the data of the transport for the reported macrocycles are also indicated for the sake of comparison. In the case of protonated phenylglycinol, increased enantioselec-tivity was obtained in the applied system. In the latter case I also examined the time dependence of the transport proving the feature of its active behaviour (Fig. 5).
The synthesis of fluorescent sensor molecules has a long tradition in our research group. Crown ethers with various structures are able to recognize the enantiomers of chiral protonated amines with different enantioselectivities values. I aimed to prepare both enantiomers of a fluorescent sensor molecule containing phosphorus $((S, S)-\mathbf{1 3}$ and $(R, R)-\mathbf{1 3}$, Fig. 6.) and also to study their enantio-meric recognition for phenylethyl amine hydrogen perchlorate (PEA), 1-(1-naphthyl)ethyl amine hydrogen perchlorate (NEA), phenylglycine methyl ester hydrogen perchlorate (PGME) and phenylalanine methyl ester hydrogen perchlorate (PAME) (Fig. 7.) by fluorescent spectroscopy ${ }^{14}$. Gergö Dargó and György Tibor Balogh performed the calculations for the complex stability constants ${ }^{15}$ (Fig. 9). The results show that macrocycles $(R, R)-\mathbf{1 3}$ and $(S, S)-\mathbf{1 3}$ form termodinamically stable complexes with the enantiomers of the chiral protonated amines, but the macrocycles exhibited moderate enantiomeric differentiation abilities ${ }^{14}$.

A few years ago small amounts of macrocycles 18, $(R, R)-19$ and $(S, S)$-20 (Fig. 10.) containing a triphenylphosphine unit were prepared in our research group ${ }^{11}$. During my work, I was able to prepare these crown ethers in larger quantities by reproducing the described synthetic routes and this way it was possible to study these compounds as catalyst ligands in the hydroformylation reaction of styrene, which were performed by Péter Pongrácz and László Kollár (Fig. 10.). The effect of platinum-ligand ratio, reaction time and temperature for the reaction was investigated during the experiments. The chemoselectivity was between 63 and $90 \%$, the regioselectivity was around $60 \%$, and the branched aldehyde was formed in the largest quantity. If chiral ligand was used, moderate enantioselectivities were achieved, 2-phenylpropanal was formed with the highest (52\%) enantiomeric excess when the $(S, S)$-20 macrocycle was used ${ }^{16}$.

In order to extend this research, I prepared six new macrocycles $((S, S)-\mathbf{2 1}-(S, S, S, S)-\mathbf{2 6})$ containing triphenylphosphine units, and two crown ethers $((S, S)-27$ and $(S, S)-28)$ containing a secondary phosphine oxide unit (Fig. 11. $)^{17}$. Secondary phosphine oxides exist in an equilibrium between the pentavalent phosphine oxide and the trivalent phosphinious acid forms. In the presence of a transition metal, the equilibrium is shifted to the phosphinous acid form through coordination of the phosphorus atom giving a rich family of potential catalysts, which are less sensitive to oxida$\operatorname{tion}^{18}$. With the help of the newly synthesized macrocycles, the relationship between the structure of the ligands and the selectivity values of the chosen model reaction can be investigated. 